\title{
Blended Fertilizers Effects on Maize Yield and Yield Components of Western Oromia, Ethiopia
}

\author{
Dagne Chimdessa \\ Oromia Agricultural Resaerch Institute, Bedele Soil Research Center, Bedele, Ethiopia
}

Email address:

dagnechimdessa@yahoo.com

\section{To cite this article:}

Dagne Chimdessa. Blended Fertilizers Effects on Maize Yield and Yield Components of Western Oromia, Ethiopia. Agriculture, Forestry and Fisheries. Vol. 5, No. 5, 2016, pp. 151-162. doi: 10.11648/j.aff.20160505.13

Received: July 17, 2016; Accepted: July 28, 2016; Published: August 21, 2016

\begin{abstract}
Appropriate fertilization practices based on actual limiting nutrients and crop requirement for a given crop is economic and judicious use of fertilizers for sustainable crop production. In view of this, a study was conducted at Kejo and Ongobo farmers' fields, located at GobuSeyo District of East Wollega Zone of Oromia region in 2011 to evaluate the effects of blended fertilizers for maize production. The five treatments used for the field experiment were control (without fertilizer), recommended $\mathrm{NP}$, recommended $\mathrm{NP}+\mathrm{Cu}+\mathrm{Zn}$, blended fertilizer and blended fertilizer $+\mathrm{Cu}+\mathrm{Zn}$. The treatments were laid out in RCBD design with four replications. The results of the study revealed that the analysis of variance among fertilizers types showed significant differences $(\mathrm{P} \leq 0.05)$ on almost all the maize characters tested. However, applied $\mathrm{Cu}$ and $\mathrm{Zn}$ to either of the recommended NP fertilizers or blended fertilizer showed no significant difference on maize agronomic characters and yield except leaf area. The shortest mean days to $50 \%$ tasseling (85.25), silking (87.25) and maturity (154.25) of maize were obtained from blended fertilizers with $\mathrm{Cu}$ and $\mathrm{Zn}$, whereas the longest days were recorded for the control plot. The maximum mean grain yield $\left(8399.7 \mathrm{~kg} \mathrm{ha}^{-1}\right)$, stover yield $\left(8553.1 \mathrm{~kg} \mathrm{ha}^{-1}\right)$ and total biomass yield $\left(16867.7 \mathrm{~kg} \mathrm{ha}^{-1}\right)$ were recorded for blended fertilizers with $\mathrm{Cu}$ and $\mathrm{Zn}$, whereas the lowest mean grain yield $\left(2824.8 \mathrm{~kg} \mathrm{ha}^{-1}\right)$ were recorded for control. Blended fertilizers had improved grain nutrient uptakes and agronomic efficiency of maize. It was also apparent that much of the nutrients applied were assimilated by the grain than that achieved by the stover. The result of the study showed that blended fertilizers increased maize productivity compared to the previously existing NP fertilizers in the country and appropriate fertilization practices can improve the current situation.
\end{abstract}

Keywords: Blended Fertilizer, Maize Yield, Nutrient Uptakes, NP Fertilizers

\section{Introduction}

Soil fertility maintenance is a major concern in tropical Africa, particularly with the rapid population increase, which has occurred in the past few decades. Improving food production and soil resources in the smallholder farm sector of Africa has become an enormous challenge [1]. The main determinant of Africa's position at the bottom of the development scale is the need to tackle soil fertility depletion as the fundamental constraints [2]. For many cropping systems in Africa, nutrient balances are negative that indicating soil mining [3]. [2] reported large per hectare losses of N, P and $\mathrm{K}$ during the last 30 years in about 100 million hectares of cultivated land in Africa (-700, -100 and $-450 \mathrm{~kg} \mathrm{ha}^{-1} 30$ years ${ }^{-1}$ for $\mathrm{N}, \mathrm{P}$ and $\mathrm{K}$, respectively) in contrast to large positive nutrient balances in North America (+200, +700 and $+1000 \mathrm{~kg}$ $\mathrm{ha}^{-1} 30$ years $^{-1}$ for N, P and K, respectively. The balances for NPK, the major plant nutrients, are taken as useful indicators of sustainability of cropping systems [4]. On the other hand [5] estimated the net losses of essential plant nutrients to be about $50 \mathrm{kgha}^{-1}$ year $^{-1}$ in Africa. If nutrient loss continues at this alarming rate, it may only be few years before crop yield targets cannot be realized [6]. Therefore, to realize a sustainable development in Africa, sustainable soil fertility replenishment strategy that has the potential to supply nutrients must be found.

In Ethiopia, agriculture provides an employment to $85 \%$ of the population, contributes $90 \%$ of the total export earnings, supplies over $70 \%$ of the total raw materials required by industries and accounts for $60 \%$ of the country's gross domestic product [7]. It plays a great role in Ethiopia's economic growth and will command the lead for many years to come [8]. Since the Ethiopian agriculture is characterized 
by low production per unit area and poor agricultural practices, the country is facing a serious and chronic problem of food shortage [9]. Unless something is done to restore soil fertility first, other efforts to increase crop production would end up with little success [10].

Inorganic fertilizers have been the important tools to overcome soil fertility problems and they are also responsible for a large part of the food production increases worldwide [2]. It has been estimated that at least 30 to $50 \%$ of crop yield increment is attributable to application of commercial fertilizers $[11,12]$. Like in other developing countries, information on soil fertility status is not adequate to meet the requirement of agricultural development programs, rational fertilizer promotions and recommendations based on actual limiting nutrients for a given crop in Ethiopia. The prevailing blanket fertilizer rate recommendation throughout the country on all soil types and agro ecological zone justifies the existence of little information on the fertility status of Ethiopia's soils.

Low soil fertility is highly affects the growth and development of maize as compared to other crops. As a result, it is often said "maize speaks" implying that maize cannot produce maximum yields unless sufficient nutrients are available [13]. When the soil does not supply sufficient nutrients for normal plant growth application of supplemental nutrients are required. The proper application rates of plant nutrients are determined by knowledge about the nutrient requirement of the crop and the nutrient supplying power of the soil [14].

In Ethiopia, maize is first in productivity and second in area coverage after teff [7]. Research results in high potential maize growing areas are in average $7000-8000 \mathrm{~kg} \mathrm{ha}^{-1}$. However, yield levels obtained by small scale farmers remained stagnant despite the availability of improved varieties [15]. One of the main causes for this discrepancy is the low use of external inputs, leading to negative balances for N, P and K [16]. In the 1970 's, technologies dealing with soil fertility issues were developed following the first paradigm in tropical soil fertility research: "overcome soil constraints to fit plant requirements through purchased inputs" [17]. Application of fertilizers in relation to initial soil fertility status and crop requirement leads to economic and judicious use of fertilizers. Experiments conducted by different researchers to decide rate of fertilizer under different research stations and their surrounding on-farm resulted in different rates of recommendations in terms of both $\mathrm{P}$ and $\mathrm{N}$ [18]. Trials carried out in many localities across Ethiopia for about nine years also recommend different rates of $\mathrm{P}$ and $\mathrm{N}$ in accordance to crop and soil types [19]. However, the current maize grain yield has declined regardless of using improved maize varieties and NP fertilizers even in high maize growing potential areas of western Oromia.

Understanding plant nutrients requirement of a given area has vital role in enhancing crop production and productivity on sustainable basis. Hybrid maize grown with high levels of macronutrients are in many cases causing a depletion of micronutrients at a rate that the soil can no longer make good [20]. Nevertheless, little information is available on blended fertilizers requirement including macro and micro plant nutrients. Increasing yields through the application of nitrogen and phosphorus alone can deplete other nutrients [21]. However, crop productivity can also be limited because of toxicity and/or deficiency of essential plant nutrients. Therefore, understanding the plant nutrients requirement of an area could help to implement demand-driven soil fertility management practices. Hence. the objective of this study was to evaluate the effects of blended fertilizers in smallholder maize based farming systems in western Oromia.

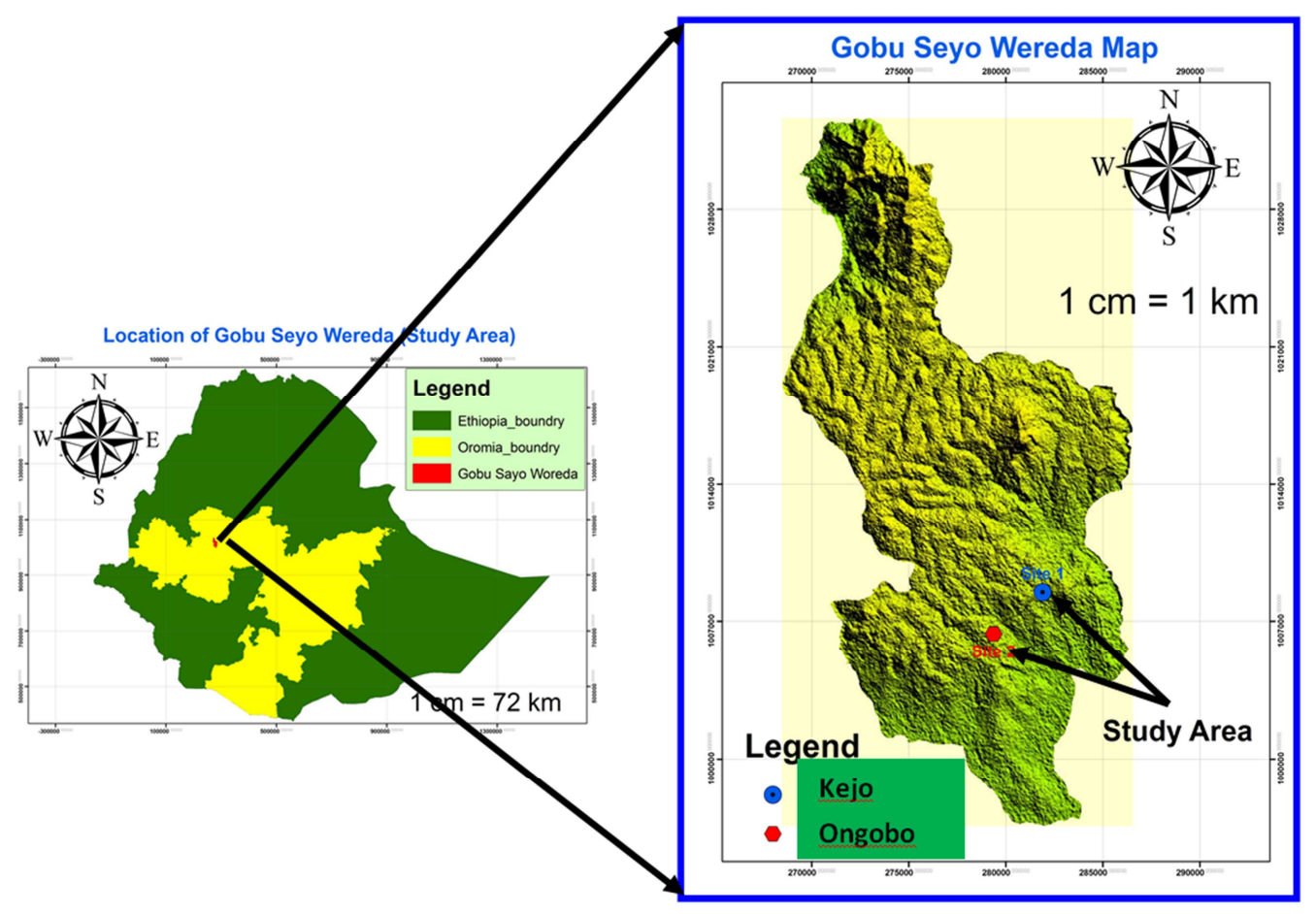

Figure 1. Location map of the study district (GobuSeyo) - East Wollega Zone, Oromia National Regional State. 


\section{Materials and Methods}

\subsection{General Description of the Study Area}

The study was conducted at Kejo and Ongobo peasant associations of GobuSeyo District in East Wollega Zone of Oromia National Regional State, western Ethiopia. GobuSeyo is located at $36^{\circ} 53^{\prime} 11^{\prime \prime}$ to $37^{\circ} 03^{\prime} 06^{\prime \prime}$ east longitude and $9^{\circ} 01^{\prime} 01^{\prime \prime}$ to $9^{\circ} 20^{\prime} 33^{\prime \prime}$ north latitude with altitude ranging from 1500 to 2500 masl and $266 \mathrm{~km}$ west of Addis Ababa. Kejo is located at $37^{\circ} 00^{\prime} 55^{\prime \prime}$ east and $9^{\circ} 07^{\prime} 05^{\prime \prime}$ northat an altitude of 1808 masl; where as Ongobo is located at $36^{\circ} 59^{\prime} 33^{\prime \prime}$ east longitude and $9^{\circ} 05^{\prime} 57^{\prime \prime}$ northlatitude at an altitude of 1758 masl. (figure 1)

The ten years (2002-2011) weather information at nearby study area (Bako Agricultural Research Center) revealed a uni-modal rainfall pattern with average ten years annual rain fall of $1283.4 \mathrm{~mm}$ The rainy season covers April to October and the maximum rainfall is received in the months of June, July and August. The minimum, maximum and average ten years annual air temperatures are $13.5,28.5$ and $21.0^{\circ} \mathrm{C}$, respectively. The predominant soil type in southwest and western Ethiopia in general and the study area in particular is Nitisols according to the [22] soil classification. Its vernacular name is "BiyeDima" meaning red soil. On the average, the soil is deep and relatively highly weathered, well drained, clay in texture and strongly to moderately acidic in reaction. Nitisols are highly weathered soils in the warm and humid areas of the west and southwest Ethiopia [23].

\subsection{Treatments, Experimental Designs and Procedures}

The field experiment was conducted at two sites of farmers' fields within the district during the 2011 cropping season with rain feed to evaluate Togo blended fertilizer(26-11-11)N- $\mathrm{P}_{2} \mathrm{O}_{5}-$ $\mathrm{K}_{2} \mathrm{O}+3.5 \mathrm{~S}+0.15 \mathrm{~B}_{2} \mathrm{O}_{3}+0.6 \mathrm{Zn}$ for maize production on Nitisols. The treatments of the experiments were control (without fertilizer), recommended NP, recommended $\mathrm{NP}+\mathrm{Cu}+\mathrm{Zn}$, blended fertilizer and blended fertilizer $+\mathrm{Cu}+\mathrm{Zn}$. The recommended NP fertilizers for maize production in the study area are $110 \mathrm{~kg} \mathrm{~N}^{-1}$ and $46 \mathrm{~kg} \mathrm{P}_{2} \mathrm{O}_{5} \mathrm{ha}^{-1}$. Whereas $35 \mathrm{~kg} \mathrm{P}_{2} \mathrm{O}_{5}$ $\mathrm{ha}^{-1}, 84 \mathrm{~kg} \mathrm{~N} \mathrm{ha}^{-1}$ and $50 \mathrm{~kg} \mathrm{~K}_{2} \mathrm{SO}_{4}$ ha $^{-1}$ were supplied to the blended fertilizer as Triple Supper Phosphate (TSP), urea and potassium sulfate $\left(\mathrm{K}_{2} \mathrm{SO}_{4}\right)$ respectively, in order to bring the macro nutrients of blended fertilizer equal to recommended level. Copper $(\mathrm{Cu})$ in the form of Cuptrac $50 \%$ and $\mathrm{Zinc}(\mathrm{Zn})$ in the form of Zintrac $70 \%$ were applied at the rate of $5 \mathrm{~L} \mathrm{ha}^{-1}$. At both sites, the treatments were laid out in a randomized complete block design (RCBD) with four replications.

Soil samples collected from the experimental fields at the depth of 0-15 cm before planting were prepared and analyzed following standard laboratory procedures for some selected soil properties. The experimental fields were prepared by using oxen plow in accordance with conventional farming practices followed by the farming community in the area where, the fields were plowed four times. The gross plot size was $16 \mathrm{~m}^{2}(4 \mathrm{~m} \times 4 \mathrm{~m})$ that accommodated five maize plants rows as an experimental unit with $8.4 \mathrm{~m}^{2}(2.4 \mathrm{~m} \times 3.5 \mathrm{~m})$ net plot. Hybrid maize (BH 660) which is high yielder as compared to other improved maize varieties in the study areas was used as a test crop on both sites that was planted in rows with spacing of $80 \mathrm{~cm}$ between rows and $25 \mathrm{~cm}$ among plants within a row. Planting was done on May 30, 2011.Two seeds of maize were planted per hill and after emergence; thinned to one plant per hill. Blended fertilizer, DAP, TSP and $\mathrm{K}_{2} \mathrm{SO}_{4}$ were applied at planting. Since the N content of DAP and blended fertilizer was not equal, the difference was applied to DAP at planting as urea in order to balance the $\mathrm{N}$ content between fertilizers. The remaining $\mathrm{N}$ was applied in split, half at 35 and 65 days after planting in the form of urea. Furthermore $\mathrm{Cu}$ and $\mathrm{Zn}$ were foliar applied in two split doses each at 30 and 40 days after planting. The $\mathrm{Cu}$ and $\mathrm{Zn}$ solutions were prepared in 200 and 30 Littre of water per hectare, respectively. During the different growth stages of the crop, all the necessary field management practices were carried out as per the practices followed by the farming community around the areas. In order to avoided boarder effects, both ends of the rows and row length of a plot were left. Hence, $8.4 \mathrm{~m}^{2}(2.4 \mathrm{~m} \times 3.5 \mathrm{~m})$ of net plot size was used for the data collection.

\subsection{Agronomic Data Collection}

Data on plant basis was recorded from the three central rows $\left(8.4 \mathrm{~m}^{2}\right)$ out of the five rows per plot. The crop data collected include plant height, leaf area, days to $50 \%$ (tasseling, silking and maturity), number of cobs per ten plant, ear length, number of kernel rows per cob, number of kernels per row and thousand kernel weight, (grain, stover and total biomass) yield.

The height $(\mathrm{cm})$ of ten randomly selected plants per plot were measured from ground level to the point where the tassel started branching when $50 \%$ of the plants in the plot reached tasseling stage and the mean value was taken as plant height. Leaf area $\left(\mathrm{cm}^{2}\right)$ was determined on ten randomly selected plants per plot with the method developed by [24]; LA=WxLx0.733 where, $\mathrm{LA}=$ leaf area $\left(\mathrm{cm}^{2}\right) ; \mathrm{W}=$ maximum leaf width $(\mathrm{cm}) ; \mathrm{L}=$ maximum leaf length $(\mathrm{cm}) ; 0.733=$ correction factor for maize and the mean value was taken as LA per plant for each plot. Days to tasseling, silking and physiological maturity of maize were recorded when $50 \%$ of the plants in a plot reached to their respective phenological stages. The number of cobs of ten randomly taken plants was counted from the central three rows of each plot. Ear length was measured from ten randomly selected ears per plot after harvest and the average value was recorded for each plot. The number of kernel rows per cob was counted on ten representative ears and the average value was recorded for each plot. The number of kernels per row was determined by counting the number of kernels per row from ten randomly taken ears and the average value was registered for the plot. Thousand grain weights was determined by counting and weighing from the bulk of shelled grain at $12.5 \%$ moisture level and expressed in grams for each plot. Grain and stover yields were determined by harvesting the entire net plot area of $8.4 \mathrm{~m}^{2}$ and converted into kilogram per hectare. Grain yield was 
adjusted to $12.5 \%$ moisture level; whereas stover yield was weighed after leaving it in open air for 7 days. The above ground total biomass yield was calculated as the sum of the grain and stover yields.

\subsection{Plant tissue Sampling and Analysis}

Stover and grain plant tissue samples were collected randomly from the net plot area at harvest from each plot and bulked over replication for the determination of $\mathrm{N}, \mathrm{P}$ and $\mathrm{K}$ contents in aboveground vegetative parts (stover) and grains using standard procedures. Total N, P and K uptakes in the plant vegetative parts and the grains were calculated by multiplying $\mathrm{N}, \mathrm{P}$ and $\mathrm{K}$ content with respective stover and grain yield per hectare. Total N, P and K uptake by whole plant were calculated by summing up the $\mathrm{N}, \mathrm{P}$ and $\mathrm{K}$ uptake by grains and stover respectively. Apparent N, P and K recovery (AR) in the above ground biomass for each fertilized treatment were calculated as the total uptake (TU) of each fertilized treatment minus TU of control divided by fertilizer applied.

$$
A R=\frac{\text { TU fertilized treatment }-\mathrm{TU} \text { of controls }}{\text { Fertilizer applied } \mathrm{kgha}^{-1}}
$$

Agronomic efficiency (AE) of fertilizer N, P and K were calculated as grain yield of each fertilized treatment minus grain yield of control divided by the fertilizer applied.

$$
\mathrm{AE}=\frac{\text { Grain yield of fertilized treatment }- \text { grain yield of control treatment }}{\text { Fertilizer applied } \mathrm{kg} \mathrm{ha}^{-1}}
$$

\subsection{Statistical Analysis}

The collected agronomy data were subjected to analysis of variance (ANOVA) using SAS computer program following the procedures described by [25]. Mean separation of significant treatments were carried out using the least significant difference (LSD) test at $\mathrm{P} \leq 0.05$ level.

\section{Results and Discussion}

\subsection{Soil Physicochemical Properties Before Planting}

Soil samples collected and analyzed from the experimental fields at the depth of $0-15 \mathrm{~cm}$ before planting for some selected soil properties (Table 1). The soil is clayey in texture and strongly acidic in reaction. The bulk density values was within normal range of mineral soils. The soil organic matter, total nitrogen, available phosphorus, exchangeable bases and available micro nutrients were low contents in the soil. Generally the result of the study showed that the soils of the study sites had poor chemical fertility.

Table 1. Soil physicochemical properties of the experimental sites before planting.

\begin{tabular}{lll}
\hline Soil properties & Kejo & Ongobo \\
\hline Textural class & Clay & Clay \\
\hline Bulk density $\left(\mathrm{g} \mathrm{cm}^{-3}\right)$ & 1.26 & 1.27 \\
$\mathrm{pH}\left(\mathrm{H}_{2} \mathrm{O}\right)$ & 5.27 & 5.41 \\
$\mathrm{OM}(\%)$ & 3.67 & 3.76 \\
Total N $(\%)$ & 0.18 & 0.19 \\
\hline
\end{tabular}

\begin{tabular}{lll}
\hline Soil properties & Kejo & Ongobo \\
\hline Textural class & Clay & Clay \\
\hline A.vP $\left(\mathrm{mg} \mathrm{kg}^{-1}\right)$ & 4.00 & 3.94 \\
$\mathrm{CEC}\left(\mathrm{cmol}_{\mathrm{c} g} \mathrm{~kg}^{-1}\right)$ & 15.21 & 20.90 \\
Exchangeable bases $\left(\mathrm{cmol}_{\mathrm{c}} \mathrm{kg}^{-1}\right)$ & & \\
Exchangeable Ca & 3.01 & 4.50 \\
Exchangeable $\mathrm{Mg}$ & 1.56 & 1.60 \\
Exchangeable K & 0.38 & 0.40 \\
Exchangeable Na & 0.05 & 0.06 \\
Available $\mathrm{Micronutrients}\left(\mathrm{mg} \mathrm{kg}^{-1}\right)$ & & \\
Available Fe & 31.04 & 35.68 \\
Available $\mathrm{Mn}$ & 74.55 & 83.91 \\
Available $\mathrm{Cu}$ & 2.12 & 2.32 \\
Available $\mathrm{Zn}$ & 0.22 & 0.30 \\
\hline
\end{tabular}

$\mathrm{OM}=$ Organic matter; Total $\mathrm{N}=$ Total nitrogen; $\mathrm{C}: \mathrm{N}=$ Carbon to nitrogen ratio, Av. $\mathrm{P}=$ Available phosphorus; $\mathrm{CEC}=$ Cation exchange capacity; $\mathrm{PBS}=$ Percent base saturation, $\mathrm{Ca}=\mathrm{Calcium}, \mathrm{Mg}=$ Magnesium, $\mathrm{K}=$ Potassium, $\mathrm{Na}=$ Sodium, $\mathrm{Fe}=$ Iron, $\mathrm{Mn}=$ Manganese, $\mathrm{Cu}=$ Copper, $\mathrm{Zn}=\mathrm{Zinc}$

\subsection{Crop phenology and Growth Parameters}

\subsubsection{Plant Height and Leaf Area}

The mean of plant height and the analysis of variance are shown in (Table 2), There were significant variations $(\mathrm{p} \leq 0.05)$ among the fertilizers types on maize height at both sites. Application of blended fertilizer significantly increased plant height as compared to the recommended NP fertilizers and the control. Similarly, the recommended NP fertilizers also significantly increased plant height as compared to the control. However, supplementation of $\mathrm{Cu}$ and $\mathrm{Zn}$ to either of the recommended NP fertilizers or blended fertilizer did not bring about a significant difference in plant height. This increment in plant height might be due to increase in cell elongation and more vegetative growth attributed to different nutrient content of Togo blended fertilizer (26-11-11)N- $\mathrm{P}_{2} \mathrm{O}_{5}$ $\mathrm{K}_{2} \mathrm{O}+3.5 \mathrm{~S}+0.15 \mathrm{~B}_{2} \mathrm{O}_{3}+0.6 \mathrm{Zn}$ containing NPKS and micronutrients). On the other hand the least plant height in unfertilized plots might have been due to low soil fertility level in the study area. In conformity with the results obtained from this study, Plant growth and development may be retarded significantly if any of nutrient elements is less than its threshold value in the soil or not adequately balanced with other nutrient elements [26]. Thus, the results indicate that blended fertilizers application has enhanced the maize vegetative growth.

\begin{tabular}{|c|c|c|c|c|}
\hline \multirow{2}{*}{ Treatments } & \multicolumn{2}{|c|}{ Plant height (cm). } & \multicolumn{2}{|c|}{ Leaf area $\left(\mathrm{cm}^{2}\right)$. } \\
\hline & Kejo & Ongobo & Kejo & Ongobo \\
\hline Control & $166.50 \mathrm{c}$ & $181.00 \mathrm{c}$ & $5642.27 d$ & $5661.68 \mathrm{e}$ \\
\hline Rec. NP & $261.75 b$ & $263.75 b$ & $7732.24 \mathrm{c}$ & $7788.68 d$ \\
\hline Rec. $\mathrm{NP}+\mathrm{Cu}+\mathrm{Zn}$ & $266.50 \mathrm{~b}$ & $268.00 \mathrm{~b}$ & $7830.82 b$ & $7852.82 \mathrm{c}$ \\
\hline Ble. fer & $273.50 \mathrm{ab}$ & $276.00 \mathrm{a}$ & $7869.53 b$ & $7920.25 b$ \\
\hline Ble. fer $+\mathrm{Cu}+\mathrm{Zn}$ & $277.75 \mathrm{a}$ & $278.50 \mathrm{a}$ & $7968.03 a$ & $7987.50 \mathrm{a}$ \\
\hline $\operatorname{LSD}(0.05)$ & 7.93 & 5.80 & 39.83 & 26.26 \\
\hline CV (\%) & 2.06 & 1.49 & 0.35 & 0.23 \\
\hline $\operatorname{SE}( \pm)$ & 2.57 & 1.88 & 12.92 & 8.52 \\
\hline
\end{tabular}

Table 2. Mean of plant height and leaf area of maize.

Means within a column sharing common letter(s) are not significantly different; Rec. $\mathrm{NP}=$ Recommended nitrogen and phosphorus fertilizers; Ble.fer $=$ Blended fertilizer 
Significant differences $(\mathrm{P} \leq 0.05)$ were observed among fertilizers types on the leaf area of maize at both sites (Table 2). The highest leaf area was recorded for blended fertilizers with $\mathrm{Cu}$ and $\mathrm{Zn}$. However, the lowest was recorded at the control of both sites. Application of blended fertilizer with $\mathrm{Cu}$ and $\mathrm{Zn}$ significantly increased leaf area as compared to blended fertilizer, recommended $\mathrm{NP}+\mathrm{Cu}+\mathrm{Zn}$, recommended $\mathrm{NP}$ and control. Similarly, the recommended NP $+\mathrm{Cu}+\mathrm{Zn}$ also significantly increased leaf area as compared to the recommended NP and control. This might be due to improved crop growth and development by blended fertilizer which contain $\mathrm{Zn}$ that increased utilization of applied nutrients by the crop. The result is in agreement with [27] who reported that $\mathrm{Zn}$ is closely involved in the $\mathrm{N}$ metabolism of plants which is essential for attaining the optimum leaf area, the most important indicator of size of the assimilatory system in maize to maximize harvest of the incident solar radiation. According to the same author, $\mathrm{Zn}$ deficient in plants can significantly reduce protein synthesis. Moreover, leaf area and canopy architecture, and leaf photosynthetic rate determine the rate of dry matter accumulation of the maize canopy [28]

\subsubsection{Days to 50\% Tasseling, Silking and Maturity of Maize}

Significant differences $(\mathrm{P} \leq 0.05)$ were observed among fertilizers types on the days to $50 \%$ tasseling, silking and maturity of maize at both sites (Table 3). Early tasseling, silking and maturity days were recorded with the application of blended fertilizer with $\mathrm{Cu}$ and $\mathrm{Zn}$, and followed by blended fertilizer. On the other hand, the longest days to $50 \%$ tasseling, silking and maturity were recorded for control (without fertilizers). Application of blended fertilizer hastened days to tasseling by $3.5 \%$ as compared to the recommended NP fertilizers at Ongobo, where as it decreased days to tasseling by $9.2 \%$ as compared to control. This decrease in days to tasseling with the blended fertilizer might be attributed to the impact of positive interaction of potassium with other nutrients in the blended fertilizer and $\mathrm{K}_{2} \mathrm{SO}_{4}$. This is in agreement with the findings of [29] who indicated that Potassium plays several roles in plant metabolism, and to perform these roles positively, it should interact positively with other essential nutrients. Potassium plays an important role in many biochemical and physiological processes in crop plants $[30,54]$. Among these processes rapid assimilation of absorbed $\mathrm{NH}_{4}{ }^{+}$ions, ensure $\mathrm{pH}$ stabilization, osmoregulation, membrane transport processes, and enzyme activation. Sufficient nitrogen results in rapid growth and hastened tasseling, while too little or no $\mathrm{N}$, resulted in slow growth and delayed tasseling [31].

Table 3. Mean of days to $50 \%$ tasseling, silking and maturity of maize.

\begin{tabular}{|c|c|c|c|c|c|c|}
\hline \multirow{3}{*}{ Treatments } & \multicolumn{6}{|c|}{ Days to $50 \%$} \\
\hline & \multicolumn{2}{|c|}{ Tasseling } & \multicolumn{2}{|l|}{ silking } & \multicolumn{2}{|l|}{ maturity } \\
\hline & Kejo & Ongobo & Kejo & Ongobo & Kejo & Ongobo \\
\hline Control & $95.00 \mathrm{a}$ & $94.50 \mathrm{a}$ & $99.00 \mathrm{a}$ & $98.50 \mathrm{a}$ & $159.50 \mathrm{a}$ & $158.25 \mathrm{a}$ \\
\hline Rec. NP & $90.00 \mathrm{~b}$ & $89.50 \mathrm{~b}$ & $93.00 \mathrm{~b}$ & $92.50 \mathrm{~b}$ & $158.50 \mathrm{~b}$ & $156.75 b$ \\
\hline Rec. $\mathrm{NP}+\mathrm{Cu}+\mathrm{Zn}$ & $88.75 b c$ & $89.00 \mathrm{~b}$ & $91.75 b$ & $92.00 \mathrm{~b}$ & $157.75 b$ & $156.25 b$ \\
\hline Ble. fer & $87.50 \mathrm{c}$ & $86.50 c$ & $89.00 \mathrm{c}$ & $87.50 c$ & $156.25 \mathrm{c}$ & $154.75 \mathrm{c}$ \\
\hline Ble. fer $+\mathrm{Cu}+\mathrm{Zn}$ & $85.50 \mathrm{~d}$ & $85.25 \mathrm{~d}$ & $87.50 \mathrm{c}$ & $87.25 c$ & $155.50 \mathrm{c}$ & $154.25 \mathrm{c}$ \\
\hline CV (\%) & 1.07 & 0.74 & 1.30 & 0.63 & 0.31 & 0.29 \\
\hline $\operatorname{SE}( \pm)$ & 0.48 & 0.33 & 0.60 & 0.29 & 0.25 & 0.22 \\
\hline
\end{tabular}

Means within a column sharing common letter(s) are not significantly different

Rec.NP = Recommended nitrogen and phosphorus fertilizers; Ble.fer = Blended fertilizer

Application of blended fertilizer significantly decreased days to silking as compared to recommended $\mathrm{NP}+\mathrm{Cu}+\mathrm{Zn}$, recommended NP fertilizers and control. Similarly, recommended NP fertilizers also significantly decreased days to silking as compared to control. On the other hand, supplementation the respective fertilizer types with $\mathrm{Cu}$ and $\mathrm{Zn}$ did not bring about a significant change in days to silking as compared to each fertilizer types used alone. Application of blended fertilizer hastened days to silking by six days as compared to recommended NP fertilizers at Kejo. This could be attributed to the impact of positive interaction of $\mathrm{B}$ in the blended fertilizer, which agreed with the finding of [32] who reported Positive relations between $\mathrm{B}, \mathrm{K}$ and $\mathrm{N}$ fertilizers for improving crop yields and maturity. These authors stated B fertilization along with $\mathrm{N}$ fertilizers is required for protein formation, which is associated with high photosynthetic reactivity, vigorous vegetative growth, and dark green color.

Days to physiological maturity in the same manner, has shown decreased with blended fertilizer. Accordingly, the maximum mean days to maturity was recorded for the control treatment. However, the minimum value was recorded for the blended fertilizers with $\mathrm{Cu}$ and $\mathrm{Zn}$ at both sites. The two fertilizer types (blended fertilizer and recommended NP) have significantly reduced days to maturity as compared to the control. However, addition of $\mathrm{Cu}$ and $\mathrm{Zn}$ did not significantly change the days to maturity as compared to the respective fertilizer types used alone. Compared to the control, mean values of days to maturity was decreased by three days in the blended fertilizer. Similarly, blended fertilizer reduced days to maturity by two days as compared to the recommended NP fertilizers at both sites. Blended fertilizer was related with vigorous, rapid growth and hastened maturity of maize, this might be due to the presence of $\mathrm{B}$ fertilizer in the blended fertilizer. In conformity with the results obtained from this study. Boron is important in photosynthesis and chlorophyll synthesis of plants [32]. 


\subsection{Yield and Yield Components}

\subsubsection{Number of Cobs per Ten Plants, Ear Length and Number of Kernel Rows Per Cob of Maize}

The mean values and analysis of variance of treatments on number of cobs per ten plants, ear length and number of kernel rows per cob revealed significant difference $(\mathrm{p} \leq 0.05)$ among fertilizers types at both sites (Table 4). The maximum number of cobs per ten plants 17.25 at Kejo and 17.75 at Ongobo was recorded for the application of blended fertilizer with $\mathrm{Cu}$ and $\mathrm{Zn}$, while the minimum value 10 for both sites was recorded for the control. Application of blended fertilizer increased number of cobs by 68 and $75 \%$ over the control plot at Kejo and Ongobo, respectively while no significant difference was observed between blended fertilizer and blended fertilizer + $\mathrm{Cu}+\mathrm{Zn}$. Compared to the recommended NP fertilizers, mean values of number of cobs per ten plants were increased by 15.5 and $16.7 \%$ for the application of blended fertilizer at Kejo and Ongobo, respectively. This increment in number of cobs in response to blended fertilizer which contains B, agreed with the finding of [33] who reported that application of B fertilizer to maize production encourage good cob development.

The maximum ear length $27.25 \mathrm{~cm}$ was recorded from application of blended fertilizer with $\mathrm{Cu}$ and $\mathrm{Zn}$ followed by $26.50 \mathrm{~cm}$ due to applications of blended fertilizer at Ongobo where there were no significant differences between the two fertilizer types at both sites. Similarly, application of blended fertilizer increased ear length by 83 and $86 \%$ over the control at Ongobo and Kejo, respectively while no significant difference was observed between recommended NP and recommended $\mathrm{NP}+\mathrm{Cu}+\mathrm{Zn}$ at both sites. The ear length increment with the blended fertilizer application might be attributed to good photo assimilate supply. The maximum assimilate supply should be available during maize grain filling $[34,55]$. The two to three week period after $50 \%$ silking as critical stage in the development of maize that is highly dependent on assimilate supply; the period when final kernel number is determined $[35,53]$.

Table. 4. Mean of number of cobs per ten plants, ear length and number of kernel rows per cob of maize.

\begin{tabular}{|c|c|c|c|c|c|c|}
\hline \multirow{2}{*}{ Treatments } & \multicolumn{2}{|c|}{ Number of cobs per ten plants } & \multicolumn{2}{|c|}{ Ear length (cm) } & \multicolumn{2}{|c|}{ Number of kernelrows per cob } \\
\hline & Kejo & Ongobo & Kejo & Ongobo & Kejo & Ongobo \\
\hline Control & $10.00 \mathrm{c}$ & $10.00 \mathrm{c}$ & $14.00 \mathrm{c}$ & $14.50 \mathrm{c}$ & $11.75 \mathrm{c}$ & $12.00 \mathrm{~b}$ \\
\hline Rec. NP & $14.50 \mathrm{~b}$ & $15.00 \mathrm{~b}$ & $19.25 b$ & $19.50 \mathrm{~b}$ & $12.25 \mathrm{bc}$ & $12.50 \mathrm{~b}$ \\
\hline Rec. $\mathrm{NP}+\mathrm{Cu}+\mathrm{Zn}$ & $15.00 \mathrm{~b}$ & $15.50 \mathrm{~b}$ & $19.50 \mathrm{~b}$ & $20.25 b$ & $12.50 \mathrm{~b}$ & $12.50 \mathrm{~b}$ \\
\hline Ble. fer & $16.75 \mathrm{a}$ & $17.50 \mathrm{a}$ & $26.00 \mathrm{a}$ & $26.50 \mathrm{a}$ & $13.00 \mathrm{ab}$ & $13.25 \mathrm{a}$ \\
\hline Ble. fer $+\mathrm{Cu}+\mathrm{Zn}$ & $17.25 \mathrm{a}$ & $17.75 a$ & $26.50 \mathrm{a}$ & $27.25 a$ & $13.25 \mathrm{a}$ & $13.50 \mathrm{a}$ \\
\hline $\operatorname{LSD}(0.05)$ & 0.73 & 0.77 & 1.07 & 0.82 & 0.74 & 0.74 \\
\hline CV (\%) & 3.20 & 3.30 & 3.30 & 2.43 & 3.82 & 3.78 \\
\hline SE $( \pm)$ & 0.24 & 0.25 & 0.35 & 0.26 & 0.24 & 0.24 \\
\hline
\end{tabular}

Means within a column sharing common letter(s) are not significantly different

Rec.NP $=$ Recommended nitrogen and phosphorus fertilizers; Ble.fer $=$ Blended fertilizer

The highest mean number of kernel rows per cob was recorded for blended fertilizer with $\mathrm{Cu}$ and $\mathrm{Zn}$. However, the lowest number of kernel rows per cob recorded for control. Compared to the control treatment, mean values of number of kernel rows per cob were increased by 10.4 and $10.6 \%$ in the blended fertilizer at Ongobo and Kejo, respectively. On the other hand, there was no significant difference observed between number of kernel rows per cob due to application of recommended $\mathrm{NP}$ and recommended $\mathrm{NP}+\mathrm{Cu}+\mathrm{Zn}$, and also between blended fertilizer and blended fertilizer with $\mathrm{Cu}$ and $\mathrm{Zn}$; indicated that application of $\mathrm{Cu}$ and $\mathrm{Zn}$ to either of the recommended NP or blended fertilizer did not bring about a significant difference in maize kernel rows per cob. In general, these increments of number of kernels per row with the blended fertilizer could be due to the more plant nutrient contents of blended fertilizer including (NPKS and micro nutrients). In agreement with the result of this experiment. Maize production depends mainly on the availability of essential plant nutrients and application of fertilizers [36]. Kernel number is strongly associated with assimilate availability at flowering [28].

\subsubsection{Kernels per Row and Thousand Kernel Weight of Maize}

The results of analysis of variance showed that there were significant differences $(\mathrm{P} \leq 0.05)$ among fertilizers types on kernels per row and thousand kernel weight of maize at both sites (Table 5). The highest mean number of kernels per row was recorded for the application of blended fertilizer with $\mathrm{Cu}$ and $\mathrm{Zn}$, whereas the lowest value was observed for the control at both sites. Application of blended fertilizer with $\mathrm{Cu}$ and $\mathrm{Zn}$ resulted in the highest kernels per row, which was significantly higher than control, recommended NP, recommended $\mathrm{NP}+\mathrm{Cu}+\mathrm{Zn}$, while it was statistically at par with kernels per row obtained at blended fertilizer. The mean values of kernels per row in the blended fertilizer were increased by 7.0 and $7.4 \%$ as compared to the recommended NP fertilizers at Kejo and Ongobo, respectively while it increased by $50 \%$ as compared to control at both sites. The kernels per row increment with the blended fertilizer application might be attributed to good physiological activities of the crop to attract assimilates. Maize intrinsic ability of the endosperm to attract assimilates (kernel sink 
capacity) is one of the most important physiological determinants of the grain yield of cereal crops and may be the major limitation to yield [37].

The highest (473.50 g) and lowest (253.25 g) average thousand kernel weight were obtained with the application of blended fertilizer with $\mathrm{Cu}$ and $\mathrm{Zn}$, and control, respectively. However, there was no significant difference between recommended $\mathrm{NP}$ and recommended $\mathrm{NP}+\mathrm{Cu}+\mathrm{Zn}$, and also between blended fertilizer and blended fertilizer with $\mathrm{Cu}$ and $\mathrm{Zn}$, The mean values of thousand kernel weight were increased by 5.4 and $5.2 \%$ in the blended fertilizer as compared with the recommended NP fertilizers at Ongobo and
Kejo, respectively. The more grain weight for blended fertilizer might be attributed to positive interaction of nutrients in the blended fertilizers. This result is in line with the findings of [30] that Potassium is involved in the working of more than 60 enzymes, in photosynthesis and the movement of its products (photosynthates) to storage organs (seeds, tubers, roots and fruits). [38] reported significant difference on grain yield through direct or indirect effects of $\mathrm{K}$ on other morphological and physiological parameters of maize. The final weight of the grains is thus a result of the rate at which the kernel accumulates dry matter and the duration over which this occurs [39].

Table 5. Mean of number of kernels per row and1000 kernel weight of maize.

\begin{tabular}{lllll}
\hline \multirow{2}{*}{ Treatments } & \multicolumn{2}{l}{ Number of kernelsper row } & \multicolumn{1}{l}{ 1000 kernels weight (g) } \\
\cline { 2 - 5 } & Kejo & Ongobo & Kejo & Ongobo \\
\hline Control & $33.25 \mathrm{c}$ & $33.75 \mathrm{c}$ & $253.25 \mathrm{c}$ & $255.25 \mathrm{c}$ \\
Rec. NP & $46.50 \mathrm{~b}$ & $47.00 \mathrm{~b}$ & $446.50 \mathrm{~b}$ & $447.50 \mathrm{~b}$ \\
Rec. NP $+\mathrm{Cu}+\mathrm{Zn}$ & $47.25 \mathrm{~b}$ & $47.75 \mathrm{~b}$ & $447.75 \mathrm{~b}$ & $449.50 \mathrm{~b}$ \\
Ble. fer & $49.75 \mathrm{a}$ & $50.50 \mathrm{a}$ & $469.75 \mathrm{a}$ & $471.50 \mathrm{a}$ \\
Ble. fer $+\mathrm{Cu}+\mathrm{Zn}$ & $50.00 \mathrm{a}$ & $51.25 \mathrm{a}$ & $471.25 \mathrm{a}$ & $473.50 \mathrm{a}$ \\
LSD $(0.05)$ & 1.25 & 1.15 & 5.68 & 5.80 \\
CV $(\%)$ & 1.79 & 1.62 & 0.89 & 0.90 \\
SE $( \pm)$ & 0.41 & 0.37 & 1.84 & 1.88 \\
\hline
\end{tabular}

Means within a column sharing common letter(s) are not significantly different

Rec. $\mathrm{NP}=$ Recommended nitrogen and phosphorus fertilizers; Ble.fer $=$ Blended fertilizers

\subsection{Grain, Stover and Total Above Ground Biomass Yield of Maize}

Grain, stover and total biomass yield of maize showed significant differences $(\mathrm{P} \leq 0.05)$ among fertilizers types used at both sites (Table 6). Application of blended fertilizer was significantly higher than control, recommended NP, recommended $\mathrm{NP}+\mathrm{Cu}+\mathrm{Zn}$, while it was statistically at par with grain yield obtained at blended fertilizer with $\mathrm{Cu}$ and $\mathrm{Zn}$. Similarly, there was no significant difference between yields obtained due to application of recommended NP and recommended $\mathrm{NP}+\mathrm{Cu}+\mathrm{Zn}$, indicated that addition of $\mathrm{Cu}$ and $\mathrm{Zn}$ to either of the recommended NP fertilizers or blended fertilizer did not bring about a significant change in maize yield. The highest (8399.7 $\left.\mathrm{kg} \mathrm{ha}^{-1}\right)$ and lowest $\left(1753.3 \mathrm{~kg} \mathrm{ha}^{-1}\right)$ average grain yields were obtained with the application of blended fertilizer with $\mathrm{Cu}$ and $\mathrm{Zn}$, and the control(without fertilizers), respectively.

The low yield in unfertilized plots might have been due to reduced leaf area development resulting in lesser radiation interception and, consequently, low efficiency in the conversion of solar radiation [40]. Compared to the recommended NP fertilizers, mean grain yield was increased by $7.7 \%$ with the application of blended fertilizer at Kejo and the same trend was observed at Ongobo. This increment in grain yield with the blended fertilizer which contained both macro and micro plant nutrients is an indicator of low soil fertility level in the study area for maize production. This is in agreement with the findings of [15] who stated that, although adoption of new varieties especially maize hybrid is moving fast in Ethiopia, fertilizer management techniques need to supplement the existing potential of the varieties. This showed that low soil fertility is among the greatest constraints to maize production in Ethiopia [18].

Grain yield increment with the blended fertilizer which contained potassium indicated that the need to supplement the element for maize production. [27] reported that many soils of the tropical regions are unable to supply sufficient $\mathrm{K}^{+}$to field crops. Hence, application of this element in adequate amount is essential for obtaining optimal crop yields. Many other researchers also have reported that application of potassium fertilizer increased maize yield [41, 42]. The increase in grain yield is could be attributed to beneficial influence of yield contributing characters and positive interaction of nutrients in the blended fertilizer. The association of grain yield with number of kernels per row observed in this study agreed with [43] findings who concluded that increasing the number of kernels per row contributes to an increase in grain yield of maize. The strong relationships found between grain yield and number of kernels per row and between grain yield and thousand kernels weight were also in agreement with the findings of [44] who stated that these two yield attributes are the most important components directly related to grain yield in maize. Similarly,a strong positive association of maize grain yield with number of kernels per row [45]. 
Table 6. Mean of grain, stover and total biomass yields of maize.

\begin{tabular}{|c|c|c|c|c|c|c|}
\hline \multirow{2}{*}{ Treatments } & \multicolumn{2}{|c|}{ Grain yield $\left(\mathrm{kgha}^{-1}\right)$} & \multicolumn{2}{|c|}{ Stover yield $\left(\mathrm{kgha}^{-1}\right)$} & \multicolumn{2}{|c|}{ Total biomass yield $\left(\mathrm{kgha}^{-1}\right)$} \\
\hline & Kejo & Ongobo & Kejo & Ongobo & Kejo & Ongobo \\
\hline Control & $1750.3 \mathrm{c}$ & $1953.9 \mathrm{c}$ & $2875.2 \mathrm{c}$ & $2824.8 \mathrm{c}$ & $4625.5 \mathrm{c}$ & $4778.7 \mathrm{c}$ \\
\hline Rec. NP & $7425.9 b$ & $7858.9 b$ & $7710.1 \mathrm{~b}$ & $7630.5 b$ & $15136.0 \mathrm{~b}$ & $15489.4 b$ \\
\hline Rec. $\mathrm{NP}+\mathrm{Cu}+\mathrm{Zn}$ & $7532.2 b$ & $7930.4 b$ & $7825.2 b$ & $7725.1 \mathrm{~b}$ & $15357.4 \mathrm{~b}$ & $15655.5 \mathrm{~b}$ \\
\hline Ble. fer & $8000.9 a$ & $8233.0 \mathrm{a}$ & $8411.0 \mathrm{a}$ & $8389.0 \mathrm{a}$ & $16411.9 \mathrm{a}$ & $16622.0 \mathrm{a}$ \\
\hline Ble. fer $+\mathrm{Cu}+\mathrm{Zn}$ & $8103.0 \mathrm{a}$ & $8399.7 \mathrm{a}$ & $8553.1 \mathrm{a}$ & $8468.0 \mathrm{a}$ & $16656.1 \mathrm{a}$ & $16867.7 \mathrm{a}$ \\
\hline $\operatorname{LSD}(0.05)$ & 151.80 & 188.74 & 435.35 & 347.22 & 688.49 & 664.22 \\
\hline CV (\%) & 1.50 & 1.78 & 4.00 & 3.22 & 3.28 & 3.11 \\
\hline $\operatorname{SE}( \pm)$ & 49.26 & 61.24 & 141.28 & 112.68 & 223.42 & 215.55 \\
\hline
\end{tabular}

Means within a column sharing common letter(s) are not significantly different

Rec. NP $=$ Recommended nitrogen and phosphorus fertilizers; Ble.fer $=$ Blended fertilizer

The highest $\left(8553.1 \mathrm{~kg} \mathrm{ha}^{-1}\right)$ and lowest $\left(2824.8 \mathrm{~kg} \mathrm{ha}^{-1}\right)$ average stover yields were obtained with the application of blended fertilizer with $\mathrm{Cu}$ and $\mathrm{Zn}$, and the control, respectively. Compared to the recommended NP fertilizers, mean stover yield was increased by 9 and $10 \%$ with the application of blended fertilizer at Kejo and Ongobo, respectively. Similarly, the highest $\left(16867.7 \mathrm{kgha}^{-1}\right)$ and lowest $\left(4625.5 \mathrm{~kg} \mathrm{ha}^{-1}\right)$ average biomass yields were obtained with the application of blended fertilizer with $\mathrm{Cu}$ and $\mathrm{Zn}$, and the control, respectively. Compared to the recommended NP fertilizers, mean total biomass yield was increased by 7.3 and $8.4 \%$ in the blended fertilizer at Ongobo and Kejo, respectively.

\subsection{Nitrogen, Phosphorus and Potassium Contents and Uptakes of Maize}

\subsubsection{Plant Tissue Contents and Uptake of $N$}

The highest content of $\mathrm{N}$ in the grain (1.07\%) was recorded for blended fertilizer with $\mathrm{Cu}$ and $\mathrm{Zn}$ at Ongobo, whereas the least was for control (Table 7). Grain N contents increased from the minimum of $0.55 \%$ obtained with control at Kejo to a maximum of $1.07 \%$ recorded for the blended fertilizer with $\mathrm{Cu}$ and $\mathrm{Zn}$ at Ongobo. Compared to recommended NP fertilizers, blended fertilizer had improved grain $\mathrm{N}$ contents by 21 and $25 \%$ at Ongobo and Kejo, respectively. Similarly, blended fertilizer improved grain $\mathrm{N}$ contents by 75 and $84 \%$ at Ongobo and Kejo, respectively as compared to the control. Application of Togo blended fertilizer increased grain $\mathrm{N}$ content as it did for grain yield. This study agreed with the findings of [46] who reported that agronomic practices affected not only yield, but also kernel $\mathrm{N}$ contents. The $\mathrm{N}$ content in the stover was low as compared to that in the grain. [47] indicated the main reason as why $\mathrm{N}$ content in the grain is higher than stalk nitrogen. According to their report, nitrogen is lost from the leaves and stalks immediately following silking, corresponding to the time of greatest increase in ear $\mathrm{N}$ content by remobilization of $\mathrm{N}$. Nitrogen in the grain at harvest came partly from uptake after anthesis, and partly from the stover. Accordingly, $48 \%$ of nitrogen in the grain was taken up after anthesis and about $52 \%$ was transferred from the vegetative parts [48].

Table 7. Plant tissue contents and up take of $N$.

\begin{tabular}{|c|c|c|c|c|c|c|}
\hline \multirow{2}{*}{ Treatments } & \multicolumn{3}{|c|}{$\mathbf{N}$ content $(\%)$} & \multicolumn{3}{|c|}{$\mathrm{N}$ uptake $\left(\right.$ kgha $\left.^{-1}\right)$} \\
\hline & Grain & Stover & Total & Grain & Stover & Total \\
\hline & Kejo & & & & & \\
\hline Control & 0.55 & 0.21 & 0.76 & 9.61 & 6.03 & 15.64 \\
\hline Rec. NP & 0.81 & 0.25 & 1.06 & 60.15 & 19.27 & 79.42 \\
\hline Rec. $\mathrm{NP}+\mathrm{Cu}+\mathrm{Zn}$ & 0.84 & 0.26 & 1.10 & 63.27 & 20.34 & 83.61 \\
\hline Ble. fer & 1.01 & 0.28 & 1.29 & 80.81 & 23.55 & 104.36 \\
\hline \multirow[t]{2}{*}{ Ble. fer $+\mathrm{Cu}+\mathrm{Zn}$} & 1.05 & 0.29 & 1.34 & 85.09 & 24.80 & 109.89 \\
\hline & Ongobo & & & & & \\
\hline Control & 0.60 & 0.18 & 0.78 & 11.72 & 5.08 & 16.80 \\
\hline Rec. NP & 0.87 & 0.20 & 1.07 & 68.38 & 15.26 & 83.64 \\
\hline Rec. $\mathrm{NP}+\mathrm{Cu}+\mathrm{Zn}$ & 1.01 & 0.22 & 1.23 & 80.10 & 16.99 & 97.09 \\
\hline Ble. fer & 1.05 & 0.24 & 1.29 & 86.45 & 20.13 & 106.58 \\
\hline Ble. fer $+\mathrm{Cu}+\mathrm{Zn}$ & 1.07 & 0.25 & 1.32 & 88.08 & 21.17 & 109.25 \\
\hline
\end{tabular}

Rec. $\mathrm{NP}=$ Recommended nitrogen and phosphorus fertilizers; Ble.fer $=$ Blended fertilizer 
In accordance with grain $\mathrm{N}$ contents, blended fertilizer had improved grain, stover and total $\mathrm{N}$ uptake of maize as compared to recommended NP fertilizers at both sites. Similarly, grain $\mathrm{N}$ uptake increased from the minimum of $\left(9.61 \mathrm{~kg} \mathrm{~N} \mathrm{ha}^{-1}\right)$ obtained with control at Kejoto a maximum of $\left(88.08 \mathrm{~kg} \mathrm{~N} \mathrm{ha}^{-1}\right)$ recorded for the blended fertilizer at Ongobo (Table 7). Accordingly, blended fertilizer increased grain $\mathrm{N}$ uptake by $26.4 \%$ and total biomass $\mathrm{N}$ uptake by $27.4 \%$ as compared to recommended NP fertilizers at Ongobo, and the same trend was observed at Kejo. The highest grain $\mathrm{N}$ uptake $\left(88.08 \mathrm{~kg} \mathrm{~N} \mathrm{ha}^{-1}\right)$ and contents $(1.07 \%)$ were recorded at Ongobo with the application of blended fertilizer with $\mathrm{Cu}$ and $\mathrm{Zn}$, and followed by blended fertilizer. Hence in all the cases, it was the grain yield that assimilated much of the $\mathrm{N}$ applied. These results agreed with the findings of [49] who stated that the rate of nitrogen accumulation is comparable to the rate of dry matter accumulation by the maize.

The maximum values of total $\mathrm{N}$ uptake were recorded for the blended fertilizer with $\mathrm{Cu}$ and $\mathrm{Zn}$ followed by blended fertilizer at both sites. This increment in total uptake could be due to efficient use of $\mathrm{N}$ by maize from the fertilizer applied. Total uptake of $\mathrm{N}$ supplied from fertilizer can be increased by maximum yields and efficient use of $\mathrm{N}$ [50, 53]. Higher amount of $\mathrm{N}$ uptake or accumulation in grain of crop plants is important, because crop yield is directly associated with $\mathrm{N}$ accumulated in grain. Hence, improving $\mathrm{N}$ uptake in grain may lead to improved grain yield [32].

\subsubsection{Plant Tissue Contents and Uptake of P}

The highest $\mathrm{P}$ contents at Kejo and Ongobo were 1.1 and $1.21 \%$ for grain, and 0.18 and $0.19 \%$ for Stover both of which were recorded under applications of blended fertilizer with $\mathrm{Cu}$ and $\mathrm{Zn}$ (Table 8). Application of blended fertilizer improved grain $\mathrm{P}$ contents from $83 \%$ in the control to $86 \%$ as compared to the total $\mathrm{P}$ contents at Ongobo. Application of blended fertilizer also improved grain P contents by 54 and $69 \%$ at Kejo and Ongobo, respectively over the plot receiving recommended NP fertilizers. Hence in all the cases, it was the grain yield that assimilated much of the $\mathrm{P}$ applied. These figures reasonably agreed with the findings of [51] who reported that the quantity of $\mathrm{P}$ in grain at harvest ranged from 78 to $90 \%$ of the total $\mathrm{P}$ content. At physiological maturity about $75 \%$ of the total phosphorus should be present in the maize grain [49]. At blended fertilizer with $\mathrm{Cu}$ and $\mathrm{Zn}$ the highest grain uptake and contents of $P$ were observed at both sites. Application of blended fertilizer improved grain $\mathrm{P}$ uptake by 66 and $77 \%$ as compared to recommended NP fertilizers at Kejo and Ongobo, respectively. Similarly, it also improved total biomass $\mathrm{P}$ uptake by $71 \%$ as compared to recommended NP fertilizers at Ongobo.

Table 8. Plant tissue contents and up take of $P$.

\begin{tabular}{|c|c|c|c|c|c|c|}
\hline \multirow{2}{*}{ Treatments } & \multicolumn{3}{|c|}{$P$ content $(\%)$} & \multicolumn{3}{|c|}{$P$ uptake $\left(\mathrm{kgha}^{-1}\right)$} \\
\hline & Grain & Stover & Total & Grain & Stover & Total \\
\hline & Kejo & & & & & \\
\hline Control & 0.47 & 0.11 & 0.58 & 8.23 & 3.16 & 11.39 \\
\hline Rec. NP & 0.65 & 0.15 & 0.80 & 48.27 & 11.56 & 59.83 \\
\hline Rec. $\mathrm{NP}+\mathrm{Cu}+\mathrm{Zn}$ & 0.90 & 0.16 & 1.06 & 67.79 & 12.52 & 80.31 \\
\hline Ble. fer & 1.00 & 0.17 & 1.17 & 80.01 & 14.29 & 94.30 \\
\hline \multirow[t]{2}{*}{ Ble. fer $+\mathrm{Cu}+\mathrm{Zn}$} & 1.10 & 0.18 & 1.28 & 89.14 & 15.39 & 104.53 \\
\hline & Ongobo & & & & & \\
\hline Control & 0.50 & 0.10 & 0.60 & 9.77 & 2.82 & 12.59 \\
\hline Rec. NP & 0.68 & 0.14 & 0.82 & 53.44 & 10.68 & 64.12 \\
\hline Rec. $\mathrm{NP}+\mathrm{Cu}+\mathrm{Zn}$ & 0.95 & 0.17 & 1.12 & 75.34 & 13.13 & 88.47 \\
\hline Ble. fer & 1.15 & 0.18 & 1.33 & 94.67 & 15.10 & 109.77 \\
\hline Ble. fer $+\mathrm{Cu}+\mathrm{Zn}$ & 1.21 & 0.19 & 1.40 & 101.64 & 16.08 & 117.72 \\
\hline
\end{tabular}

Rec. $\mathrm{NP}=$ Recommended nitrogen and phosphorus fertilizers; Ble.fer= Blended fertilizer

Generally, all the three maize P uptake parameters exhibited positive responses among fertilizers used. The grain $\mathrm{P}$ uptake of the crop was much higher than the stover P uptake, due to higher $\mathrm{P}$ content of the grain than that of the stover. From the maximum total $\mathrm{P}$ uptake obtained at the blended fertilizer $86 \%$ was found in the grain and $14 \%$ was contributed from the stover at Ongobo. Hence in all the cases, it was the grain yield that assimilated much of the nutrients applied.

\subsubsection{Plant Tissue Contents and Uptake of $K$}

The highest contents of $\mathrm{K}$ in the maize grain was recorded for blended fertilizer with $\mathrm{Cu}$ and $\mathrm{Zn}$, whereas the least value was recorded for control at both sites (Table 9). Similarly, at blended fertilizer with $\mathrm{Cu}$ and $\mathrm{Zn}$ the highest uptake $(29.40 \mathrm{~kg}$ $\mathrm{K} \mathrm{ha}^{-1}$ ) and contents $(0.35 \%)$ of grain $\mathrm{K}$ were recorded at Ongobo and similar trend was observed at Kejo. Compared to recommended NP fertilizers, blended fertilizer had improved grain $\mathrm{K}$ contents by 35 and $50 \%$ at Kejo and Ongobo, respectively. Similarly, blended fertilizer had improved $\mathrm{K}$ uptake in grain, stover and total maize plant by 57, 49 and $48 \%$, respectively as compared to recommended NP fertilizers at Kejo and similar trend was observed at Ongobo. 
Table 9. Plant tissue contents and up take of $K$.

\begin{tabular}{|c|c|c|c|c|c|c|}
\hline \multirow{2}{*}{ Treatments } & \multicolumn{3}{|c|}{ K content $(\%)$} & \multicolumn{3}{|c|}{ K uptake $\left(\mathrm{kgha}^{-1}\right)$} \\
\hline & Grain & Stover & Total & Grain & Stover & Total \\
\hline & \multicolumn{6}{|l|}{ Kejo } \\
\hline Control & 0.22 & 0.82 & 1.04 & 3.85 & 23.57 & 27.42 \\
\hline Rec. NP & 0.23 & 1.01 & 1.24 & 17.08 & 77.87 & 94.95 \\
\hline Rec. $\mathrm{NP}+\mathrm{Cu}+\mathrm{Zn}$ & 0.24 & 1.11 & 1.35 & 18.08 & 86.85 & 104.93 \\
\hline Ble. fer & 0.31 & 1.38 & 1.69 & 24.80 & 116.07 & 140.87 \\
\hline Ble. fer $+\mathrm{Cu}+\mathrm{Zn}$ & 0.34 & 1.94 & 2.28 & 26.94 & 165.93 & 192.87 \\
\hline Control & 0.20 & 0.75 & 0.95 & 3.91 & 21.18 & 25.09 \\
\hline Rec. NP & 0.22 & 1.06 & 1.28 & 17.29 & 80.88 & 98.17 \\
\hline Rec. $\mathrm{NP}+\mathrm{Cu}+\mathrm{Zn}$ & 0.23 & 1.27 & 1.50 & 18.24 & 98.10 & 116.34 \\
\hline Ble. fer & 0.33 & 1.47 & 1.80 & 27.17 & 123.31 & 150.48 \\
\hline Ble. fer $+\mathrm{Cu}+\mathrm{Zn}$ & 0.35 & 1.63 & 1.98 & 29.40 & 138.02 & 167.42 \\
\hline
\end{tabular}

Rec. $\mathrm{NP}=$ Recommended nitrogen and phosphorus fertilizers; Ble.fer $=$ Blended fertilizer

\subsection{Apparent Recovery of Fertilizers and Agronomic Efficiencies of Maize}

The recovery of $\mathrm{N}$ fertilizer from total $\mathrm{N}$ uptake by the total biomass at harvest varied among fertilizers types. Accordingly, the highest value of $\mathrm{N}$ recovery was recorded for blended fertilizer with $\mathrm{Cu}$ and $\mathrm{Zn}$, and followed by blended fertilizer, whereas the least value was for control at both sites. Application of Togo blended fertilizer improved $\mathrm{N}$ recovery by 35 and $40 \%$ as compared to recommended NP fertilizers at Ongobo and Kejo, respectively. In agreement with the present study, Nitrogin applied at anthesis increased N recovery [52]. They showed that split $\mathrm{N}$ application could be efficiently taken up by Maize and would not decrease $\mathrm{N}$ uptake from the soil. Similarly, the maximum values of $\mathrm{P}$ and $\mathrm{K}$ recovery were recorded for blended fertilizer with $\mathrm{Cu}$ and $\mathrm{Zn}$, and followed by blended fertilizer, whereas the least were for control at both sites.

Yield per unit application of $\mathrm{N}$ of blended fertilizer with $\mathrm{Cu}$ and $\mathrm{Zn}$ was superior to all the treatments. Accordingly, the highest agronomic efficiency of $\mathrm{N}$ was obtained by the blended fertilizer with $\mathrm{Cu}$ and $\mathrm{Zn}$ and the least was recorded for control at both sites. Blended fertilizer improved $\mathrm{N}$ use efficiency by 7.9 and $9.8 \%$ as compared to recommended NP fertilizers at Ongobo and Kejo, respectively. Similarly, the same trend was observed with $\mathrm{P}$ and $\mathrm{K}$ use efficiencies. High agronomic efficiency would be obtained if the yield increment per unit applied is high [49].

\section{Conclusions}

Rational fertilizer promotions and recommendations based on actual limiting nutrients for a given crop is not only revealed to supply adequate plant nutrients but also helped to understand the long-term ecological and economic benefits of the studied crop. Accordingly, all the studied blended fertilizers effects on maize yield and yield components showed that the blended fertilizers would be promising to grow maize in the study area, whereas maize productivity for the previously existing NP fertilizers in the country was low as compared to the blended fertilizers; which indicated that maize productivity in the study sites was reduced due to high demand for external nutrient inputs rather than NP fertilizers. The results of the study revealed that the maximum mean grain yield (8399.7 $\left.\mathrm{kg} \mathrm{ha}^{-1}\right)$, stover yield $\left(8553.1 \mathrm{~kg} \mathrm{ha}^{-1}\right)$ and total biomass yield $\left(16867.7 \mathrm{~kg} \mathrm{ha}^{-1}\right)$ were recorded for blended fertilizers, whereas the lowest were recorded for the control. The shortest mean days to $50 \%$ tasseling (85.25), silking (87.25) and maturity (154.25) of maize were recorded for blended fertilizers, whereas the longest records were obtained from the control. Blended fertilizers had improved grain nutrient uptakes and agronomic efficiency of maize. It was also apparent that much of the nutrients applied were assimilated by the grain than that achieved by the stover. To sustain and/or improve the current unbalanced fertilizer application and soil mining of the study sites, precautionary actions such as adopting sustainable soil fertility replenishment strategy, soil conservation practices and avoiding unbalanced fertilizers can help to rebuild the soil conditions to increase crop productivity. Further researches have to be continued to recommend fertilizer types and rate for the major crops grown in this region.

\section{Acknowledgement}

The author acknowledge Agricultural Development Bureau of the Oromia National Regional State for awarding the study leave and the Alliance for a Green Revolution for Africa (AGRA) for granting in financial support for research work.

\section{References}

[1] Smaling, E. M. and A. R. Braun, 1996. Soil fertility research in sub-Saharan Africa: new dimensions, new challenges. Commun. Soil Sci. and Plant Anal. J. 27: 365-386.

[2] Sanchez, A. P. and R. B. Leakey, 1997. Land use transformation in Africa: three determinants for balancing food security with natural resource utilization. Agron J. 7: 15-23.

[3] Bationo, A., F. Lompo and S. Koala, 1998. Research on nutrient flows and balances in West Africa: state-of-the-art. Agric. Ecosyst. And Environ. J. 71: 19-35. 
[4] Janssen, D. M., J. J. Stoorvogel and R. A. Schipper, 1995. Using sustainability indicators in agricultural Land Use Analysis: An example from Costa Ric. Netherlands J. Agri. Sci.,43: 61-81.

[5] Stangel, P., C. Pieri and U. Mokwunye, 1994. Maintaining nutrient status of soils: macronutrients. pp. 171-197. In: Greenland, D. J. and I. Szabolcs (eds). Soil resilience andSustain able land use. Willingford, UK: CAB International.

[6] Smaling, E. M., 1990. Two scenarios for the sub-Sahara: one leads to disaster. Cere-Rome J. 22: 19-20 and 23-24.

[7] CSA (Central Statistical Agency), 2010.Agricultural Sample Survey for the 2009/2010 cropseason. Volume II Report on Area and production of Crops for Private Peasant Holdings (Meher Season) Statistical Bulletin 446. FDRE/CSA, Addis Ababa, Ethiopia.

[8] Heluf Gebrekidan, 1985. Investigation of salt -affected soils and irrigation water quality in Melka Sedi-Amibara Plain, Rift-Valley Zone of Ethiopia. MSc Thesis, Addis Ababa University, Ethiopia. 132p.

[9] Yohannes Gebremichael, 1989. Land-Use, agricultural production and soil conservation methods in the AnditTid area, Shewa Region. Soil Conservation Research Project, Research Report 17.

[10] Quinenes, M., A. Foster, D. Akibo and N. P. Siclima, 1992. Methodology used by SG 2000 Project in Africafor transfer of improved production technologies to small scale farmer. pp. 149-153 .In: Proceeding of the First National Maize Workshop of Ethiopia, Addis Ababa.

[11] Stewart, W. M., D. W. Dibb, A. E. Johnston and T. J. Smyth, 2005. The contribution of commercial fertilizernutrients to food production. Agron J. 97: 1-6.

[12] Vlek, P. L., 1990. The role of fertilizers in sustaining agriculture in sub-Saharan Africa. Fert. Res. J. 26:327-339.

[13] Delorite, R. J. and H. L. Ahlgren, 1967. Crop Production. $\left(3^{\text {rd }}\right.$ ed). Prentice Hall, Inc., Englewood Cliffs, NewJersey.

[14] Foth, H. D. and B. G. Ellis, 1997. Soil Fertility, (2 ${ }^{\text {nd }}$ ed). Lewis Publishers, Boca Raton, Florida. 290p.

[15] Benti Tolessa, 1993. The need and objective of the $1^{\text {st }}$ National Maize Workshop. In: Proceedings of the $1^{\text {st }}$ National Maize Workshop of Ethiopia. 5-7 May, 1992, IAR and IMWIC, Addis Ababa, Ethiopia.

[16] Rhodes, E., A. Bationoa, E A. Smaling and A. Viskerc, 1996. Nutrient stocks and flows in West African soils. Pp: 22-32. In: AUMok Wuange, A. deJager and E. M. A. Smaling (eds). Key to sustainable development.

[17] Sanchez, A. P. 1994. Tropical soil fertility research: Towards the second paradigm Vol. 1 . Transactions $5^{\text {th }}$ world congress of soil science. Acapalco, Mexico.

[18] Kelsa Kena, Tadesse Yoannes and Tesfa Bogale, 1992. Influence of fertilizer and its management practices onmaize grain yields in major maize producing areas of Ethiopia. In: proceedings of the first national maize work shop of Ethiopia. IAR (Institute of Agricultural Research), Ethiopia.

[19] Ho, C. T., 1992. Results of fertilizer trials conducted on major cereal crops by ADD/NFIU. Joint Working Paper No. 43. Addis Ababa, Ethiopia. 83p.
[20] Onwuene, I. C. and T. D. Sinha, 1991. Field crop production in Tropical Africa: Principles and Practice. Published by CTA, Wageningan. Netherlands.

[21] FAO (Food and Agriculture Organization), 2000. Fertilizers and their use. International Fertilizer Industry Association. Food and Agriculture Organization of the United Nations Rome, Italy.

[22] FAO (Food and Agriculture Organization), 2001. Lecture notes on the major soils of the world. Driessen, P., J. Deckers, and F. Nachtergaele, (eds.). Food and Agricultural Organizations, Rome, Italy. 334p.

[23] Mesfin Abebe, 1998. Nature and management of Ethiopian soils. Alemaya University, Ethiopia. 272p.

[24] Mckee, G. W., 1964. A coefficient for computing leaf area of hybrid corn. Agron. J.56: 240-241.

[25] Gomez, K A. and A. A. Gomez, 1984.Statistical Procedures for Agricultural Research. ( $2^{\text {nd }}$ ed). John Wiley and Sons. New York, USA. 680p.

[26] Landon, J. R., 1991. Booker tropical soil manual: A Handbook for Soil Survey and Agricultural Land Evaluation in the Tropics and Subtropics. Longman Scientific and Technical, Essex, New York. 474p.

[27] Fageria, N. K. and V. C. Baligar, 2005. Growth components and zinc recovery efficiency of upland ricegenotypes. Agron J. 40: $1211-1215$.

[28] Tollenaar, M. and L. M. Dwyer, 1999.Physiology of maize. In: Smith, D. L. and C. Hamel.Crop yield, physiology and process.Springer-Verlag Berlin Heidelberg.

[29] Dibb, D. W. and W. R. Thompson, 1985. Interaction of Potassium with other nutrients.pp515-533. In: Munson, R. D (eds). Potassium in agriculture. Madison.

[30] FAO (Food and Agriculture Organization), 2006. Plant nutrition for food security: A guide for integratednutrient management. FAO, Fertilizer and Plant Nutrition Bulletin 16. FAO, Rome.

[31] Cock, R. L. and B. G. Ellis. 1992. Soil management, a world view of conservation Krieger Publishing Company, Malabar, Florida. 413 p.

[32] Fageria, N. K., V. C. Baligar and R. B. Clark, 2002. Micronutrients in crop production. Adv. Agron. J. 77: 185-268.

[33] Mozafar, A., 1989. Boron effect on mineral nutrition of maize.Agron. J. 81: 285-290.

[34] Ma, B. L., L. M. Dwyer and E. Gregorich, 1997.Corn yield responses to soil $\mathrm{N}$ amendments. Proceedings of $52^{\text {nd }}$ Annual Northern Corn improvement Conference. February 12-13, 1997.

[35] Frey, N. M., 1981. Dry matter accumulation in kernels of maize. Crop Sci. J.21: 118-122.

[36] Adediran, J. A. and J. O. Kogbe, 2003. Influence of nitrogen, phosphorus and potassium application on the yield of maize in the savanna zone of Nigeria. African J. Biotech. 2: 345-349.

[37] Jones, R. J., B. M. Schreiber and J. A. Roessler. 1996. Kernel sink in maize: Genotypic and material regulation. Crop Sci. J. 36: 303-306. 
[38] Cliquet, J. B., E. Deleens, A. Bousser, M. Martin, J. C. Lescure, J. L. Prioul, A. Mariotti and J. F. Morot, 1990. Estimation of Carbon and Nitrogen allocation duringstalk elongatio.

[39] Housely, T. L., A. Kirleis, H. W. Ohm and F. L. Patherson, 1982.Dry matter accumulation in soft redwinter wheat seeds. Crop Sci. J. 22: 290-294.

[40] Sallah, P. Y., N. J. Ehlke and J. L. Geadelmann. 1998. Progress from selection inmaize population evaluatedunder three nitrogen fertiliser levels. African J. Crop Sci. 6: 241-248.

[41] Grunes, A., M. Alpaslan and A. Inal, 1998.Critical nutrient concentrations and antagonistic and synergistic relationships among the nutrients of NFT-grown youngtomato plants. Plant Nutr. J. 21: 2035-2047.

[42] Johns, G. G. and I. A. Vimpany, 1999. Interaction of $\mathrm{pH}$ amendment and potassium fertilizer on soil chemistry and banana plant growth. Australian J. Agri. Res. 50: 199-210.

[43] Jugenheimer, R. W., 1985. Corn: improvement, seed production and uses. Robert E. Krieger publishing company, Malabar, Florida. 749 p.

[44] Khatun, F., S. Begum, A. Mothin, S. Yasmin and M.R. Islam, 1999.Correlationcoefficient and path analysis of some maize hybrids. Bangladesh. J. Botany: 28 (1): 9-15.

[45] Elings, A., J. White and G. O. Edmeades, 1996. Modeling tropical maize under drought and low N. Agronomy Abstracts, 1996 Annual Meeting, Indianapolis, Indiana, November 3-8, 1996. Madison, Wisconsin, USA: American Society of Agronomy.

[46] Ahamadi, M., W. J. Wiebold, J. E. Beuerlein, D. J. Eckert and J. Schoper, 1993. Agronomic practices that affect corn kernel characteristics. Agron. J. 85: 615-618.n by ${ }^{13} \mathrm{C}$ and ${ }^{15} \mathrm{~N}$ tracing in Zea mays L. Plant Physiol. J. 92: 79-87.
[47] Below, F. E., L. E. Christensen, A. J. Reed and R.H. Hageman, 1981. Availability of reduced $\mathrm{N}$ and carbohydrates for ear development of maize. Plant Physiol. J. 68: 1186-1190.

[48] Russel, M. P., E. J. Deibert, R. D. Stevanovic and R. O. Olson, 1988. Effects of water and nitrogen management on yield and $15 \mathrm{~N}$-depeleted fertiliser use efficiency of irrigated corn. Soil Sci. Soc. Am. J. 45: 553-558.

[49] Obreza, T. A. and F. M. Rhoads, 1988.Irrigated corn response to soil test indices and fertilizer nitrogen, phosphorus, potassium and magnesium. Soil Sci. Soc. Am J.52: 701-705.

[50] Sowers, K. E., W. L. Pan, B. C. Miller and T. L. Smith, 1994. Nitrogen use efficiency of split nitrogen applications in soft white winter wheat. Agron. J. 86: 942-948.

[51] Waldren, R. P. and A. D. Flower day, 1979. Growth stage and distribution of DM, N, P and K inwinter. Agron. J. 71: 391-397.

[52] Wuest, S. B. and K. G. Cassman, 1992. Fertilizer nitrogen use efficiency of irrigated wheat. I. Uptake efficiency of preplant versus late season application. Agron. J. 84: 682-688.

[53] Haney, R. L., Haney, E. B., Smith, D. R. and White, M. J. (2015) Estimating Potential Nitrogen Mineralization Using the Solvita Soil Respiration System. Open Journal of Soil Science, 5, 319-323.

[54] Sultana, S., Kashem, M. A. and Mollah, A. K. M. M. (2015) Comparative Assessment of Cow Manure, Vermicompost and NPK Fertilizers and on the Growth and Production of Zinnia (Zinnia elegans) Flower. Open Journal of Soil Science, 5, 193-198.

[55] Arif, M., I. Amin, M. T. Jan, I. Munir 3, K. Nawab, N. U. Khan, and K. B. Marwat, 2010. Effect of Plant Population And Nitrogen Levels And Methods of Application on Ear Characters and Yield of Maize. Pakistan Journal of Botany, 42 (3): 1959-1967. 